3 Maria Antonosyan $^{\mathrm{a}, \mathrm{b}}$, Frederik V. Seersholm ${ }^{\mathrm{c}}$, Alicia C. Grealy ${ }^{\mathrm{c}, \mathrm{d}}$, Milo Barham ${ }^{\mathrm{e}}$, Daniel Werndly ${ }^{\mathrm{c}, \mathrm{d}}$,

4 Ashot Margaryan ${ }^{\mathrm{f}}$, Agata Cieślik $^{\mathrm{g}}$, Thomas W. Stafford Jr. ${ }^{\mathrm{h}}$, Morten E. Allentoft $^{\mathrm{f}}$, Michael Bunce ${ }^{\mathrm{c}}$, Levon 5 Yepiskoposyan ${ }^{\mathrm{b}, \mathrm{a}}$

6

\section{Ancient DNA shows high faunal diversity in the Lesser Caucasus during}

\section{the Late Pleistocene}

a. Institute of Molecular Biology, National Academy of Sciences, 7 Hasratian Street, 0014, Yerevan, Armenia, mantonosyan@gmail.com (corresponding author)

b. Russian-Armenian University, 123 Hovsep Emin Street, 0051, Yerevan, Armenia, lepiskop@gmail.com

c. Trace and Environmental DNA Laboratory, School of Molecular and Life Sciences, Curtin University, Bentley, WA 6102, Australia, frederikseersholm@gmail.com, dan.werndly@gmail.com,michael.bunce@curtin.edu.au

d. Research School of Biology, Australian National University, Acton, ACT, 2601, Australia, alicia.grealy@uqconnect.edu.au

e. Centre for Exploration and Targeting - Curtin Node, School of Earth and Planetary Sciences, Curtin University, GPO Box U1987, Perth, WA 6845, Australia, milobarham@yahoo.co.uk

f. Lundbeck Foundation GeoGenetics Centre, Department of Biology, University of Copenhagen, Øster Voldgade 5-7, 1350 Copenhagen, Denmark, ashotmarg2004@gmail.com, $\underline{\text { morten.allentoft@gmail.com }}$

g. Department of Anthropology, Hirszfrld Institute of Immunology and Experimental Therapy, PAS, Weilgla 50-114 Wrocław, Poland, atagace@gmail.com

h. Stafford Research Labs, Inc., 200 Acadia Avenue, Lafayette, CO 80026-1845, USA, $\underline{\text { twstafford@stafford-research.com }}$ 
ABSTRACT

25

In this study, we explore the Late Pleistocene (LP) vertebrate fauna diversity in south-eastern Lesser Caucasus based on morphological and genetic identification of fossil bones from Karin Tak cave. For the first time in this under-studied region, we used a bulk bone metabarcoding genetic approach to complement traditional morphology-based taxonomic identification hampered by highly fragmented fossil bones. Excellent ancient DNA (aDNA) preservation allowed for a successful species identification of many bone remains and improved paleoenvironmental interpretations for the region. The identification of fossil bones revealed a high diversity of animal taxa inhabiting the region between ca. $>42,000$ and 25,683-24,803 calibrated years before present (cal. BP).

The reconstructed taxonomic assemblage comprises 29 taxa, including 11 mammalian and three avian families currently inhabiting the region, together with a few taxa that are regionally extinct today. Despite limited temporal resolution, the taxonomic assemblage identified points to faunal continuity in the study region during the LP. This suggests that the transition between warm and humid Marine Isotope Stage (MIS) 3 and cold and arid MIS 2 did not cause a dramatic change in the faunal makeup of the region.

\section{Keywords}

Karin Tak cave; Lesser Caucasus; Late Pleistocene; ancient DNA; Bulk bone metabarcoding; Biodiversity; Palaeoenvironmental reconstruction

\section{Introduction}

It has long been recognized that the distribution and population density of many species have expanded and contracted in tandem with glacial-interglacial cycles throughout the Quaternary (Provan and Bennett, 2008). The end of the Pleistocene witnessed a dramatic series of megafaunal extinctions and it remains debated whether human activity, climate change, or a combination of the two caused this reduction in biodiversity. Overkill hypotheses draw on the inferred characteristics of human colonization (Barnosky et al., 2004), while rapid climatically-driven environmental change, particularly associated with the 
transition from warmer interglacial Marine Isotope Stage (MIS) 3 to the last glacial cycle (MIS 2), is the main alternative extinction driver. The onset of the Last Glacial Maximum (LGM; MIS 2; 26,500 to 20 19,000 calibrated years before present (cal. BP) by Clark et al., 2009) led to ecological restructuring, species redistribution and extinctions that shaped the current environment (Provan and Bennett, 2008). During the LGM, thermophile plants and animals were confined to isolated temperate climate refugia, with their current distribution and genetic diversity often reflecting post-glacial expansions from these areas (Tarkhnishvili et al., 2012). Being climatically buffered by the Caucasus Mountains and benefiting from the ameliorating effects of the Black and Caspian Seas, the Lesser Caucasus evidently served as such a biogeographical refugium throughout the Pleistocene (Bar-Yosef et al., 2006; Fernández-Jalvo et al., 2016; Gabunia et al., 2000; Orth et al., 2002; Tarasov et al., 1846). Though the human and environmental history of this area is now being explored scientifically (Adler et al., 2008; 2014; Adler and Tushabramishvili, 2004; Bar-Oz and Adler, 2005; Bar-Yosef et al., 2011; Gasparyan et al., 2014; Kandel et al., 2017; Lordkipanidze et al., 2013; Pinhasi et al., 2011; 2014), the Late Pleistocene (LP) environment, and faunal occupation and composition history of the Lesser Caucasus at this time still remain unclear.

To address this gap and improve reconstruction of the LP environment of the Lesser Caucasus region, Karin Tak cave was explored. Test excavations at this site have yielded numerous animal bones, charcoal fragments, lithics and hominin remains. Moreover, a human tooth dated to ca. 6,900 (BP) yielded highquality ancient DNA (aDNA) (Margaryan et al., 2017), indicating that biomolecule preservation in the cave may be sufficient to help identify ancient taxa with a genetic approach.

As is commonly the case, excavations at Karin Tak have mainly provided highly fragmented and morphologically undiagnostic bones, which are not informative for reconstructing prehistoric faunal dynamics associated with climate shifts across glacial-interglacial cycles. The excavations yielded only a few bones that were taxonomically identified based on morphological traits. In this context, aDNA analysis of the fossils represents an effective complementary tool for detailed mapping of faunal diversity. 
72 Bulk bone metabarcoding is one such aDNA method that characterizes DNA extracted from

73 morphologically unidentifiable bone fragments, in order to provide records of taxonomic diversity

74 (Murray et al., 2013; Grealy et al., 2015; Seersholm et al., 2018).

75 In the current study, we aimed to estimate ancient faunal diversity using morphology-based and aDNA

76 technologies, and discuss our results in relation to the palaeoclimate and palaeoecology of the south-

77 eastern Lesser Caucasus region during the MIS 3 and early MIS 2 stages.

78

79

80

81

82

83

84

85

\section{Regional setting}

\subsection{Exploration site}

Karin Tak cave is an undisturbed site located at the south-eastern end of the Lesser Caucasus mountain range that stretches between the Black Sea in the west and the Caspian Sea in the east and delimits the north-eastern border of the Armenian Highland (Fig. 1). More specifically, the cave is situated in the midst of the lush Karintak forest, on the bank of the Karkar River. The cave is developed within thickly bedded, tabular Jurassic limestone at an elevation of 1,396 m above sea level (a.s.1.; Avagyan et al., 2018). The site derives its name from a nearby village, situated in a valley ca. $600 \mathrm{~m}$ from the cave. 


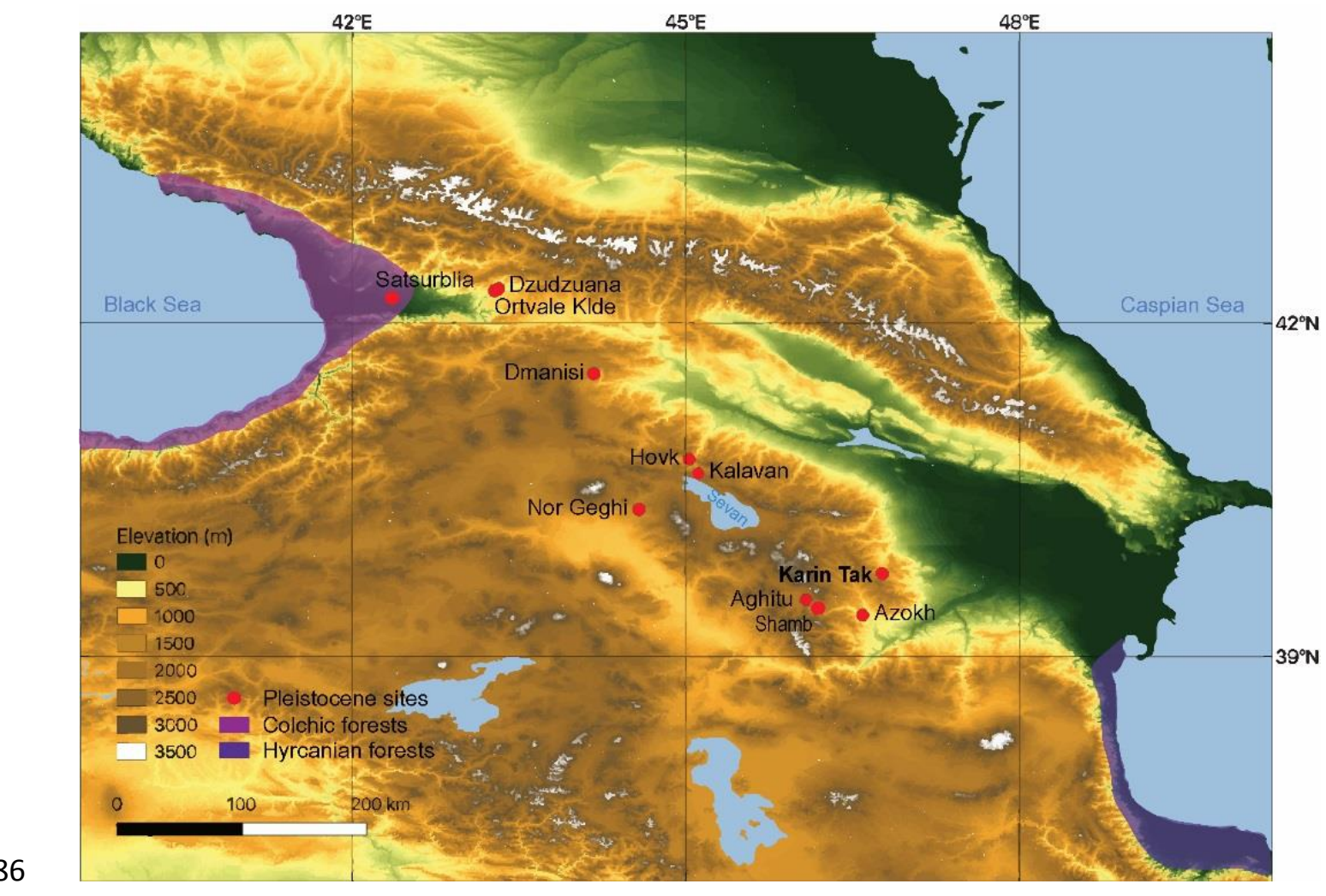

87 Fig. 1. Map of the Lesser Caucasus with Pleistocene sites, Hyrcanian and Colchic refugia. [1-column

88 fitting image]

89 The cave system comprises two separate passages conventionally termed Cave 1 and Cave 2 (Fig. 2).

90 Cave 1 is considerably longer, extending to ca. $60 \mathrm{~m}$ in a northeastern direction (inwards from the

91 entrance). It constricts and widens several times along its length producing a series of small sub-

92 chambers. Cave 2 extends in from the entrance in an eastern direction for only ca. $10 \mathrm{~m}$ before turning $90^{\circ}$

93 southward for another $5 \mathrm{~m}$. A potential (buried and inaccessible) link between these two caves is

94 tentatively suggested on the map in Figure 2. A preliminary geological survey suggested the presence of

95 an open chimney in the inner chamber of Cave 1 before the collapse of the cave system . 


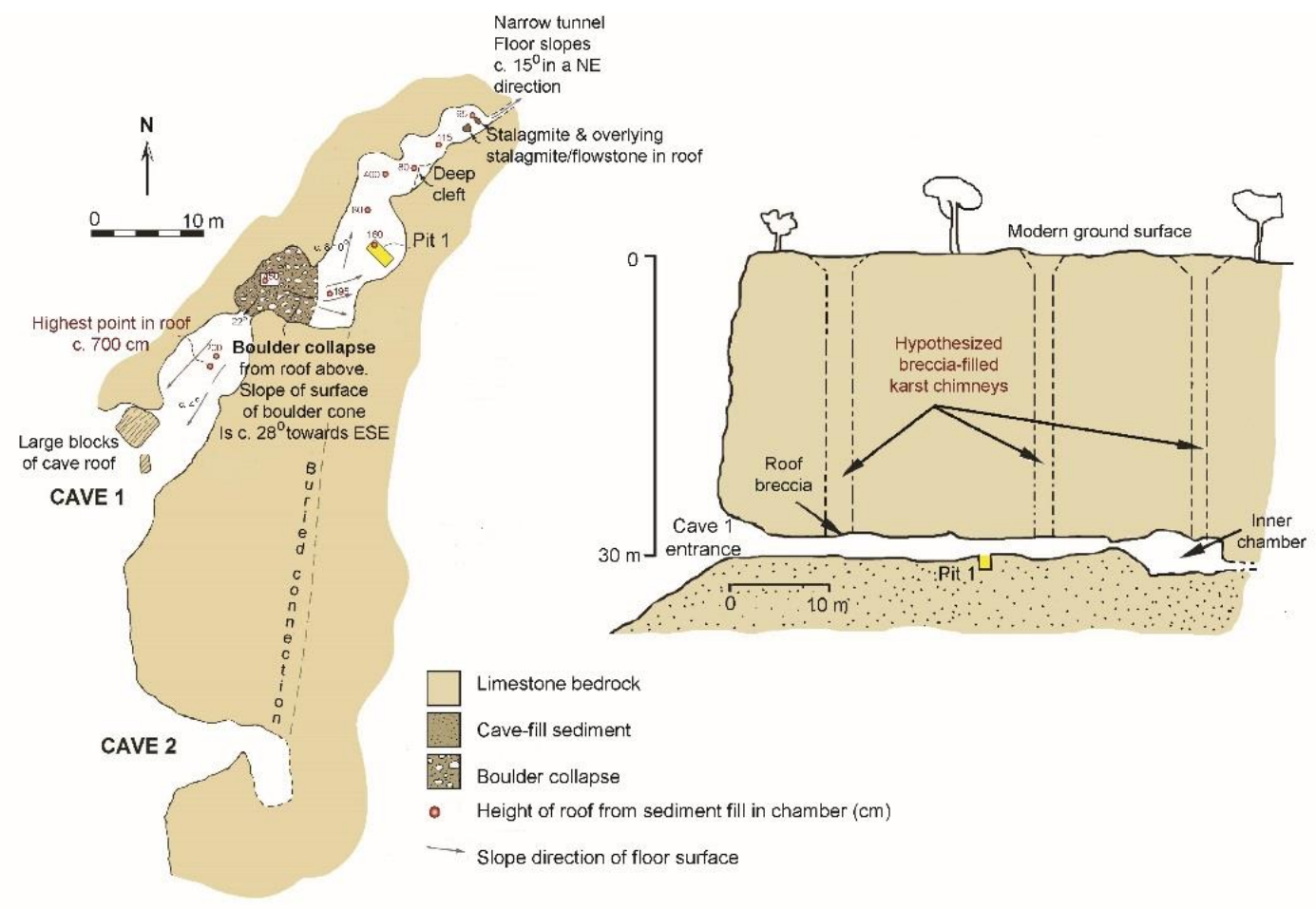

96

97 Fig. 2. Sketch map and schematic cross section of Karin Tak cave. Pit 1 is located approximately $25 \mathrm{~m}$ from the cave mouth. Vertical solution chambers (karst chimneys) are drawn hypothetically and are based on a limestone breccia and a sediment-filled chamber in the ceiling near the cave mouth and the presence of sediments with no obvious stream source. [1.5-column fitting image]

101 The currently explored extent of Cave 1 includes six chambers. Stalactites, stalagmites, and flowstone are observed in the rear of the cave. The site is still active and wet today, and exhibits minimal seasonal temperature fluctuations: $13^{\circ} \mathrm{C}$ in summer and $8^{\circ} \mathrm{C}$ during winter. Inner chambers are devoid of any daylight penetration. These conditions at the site are conducive for DNA preservation (Stone, 2000).

\subsection{Palaeoenvironmental background}

106 The mountainous relief of the Caucasus is a consequence of geological activity (collision of the Arabian and Eurasian Plates) and Pleistocene glaciations. Investigations of the last glaciation in the Lesser Caucasus revealed that the firn line was lowest on the ranges located closest to the Black Sea $(2,200-$ 
2,300 $\mathrm{m}$ a.s.1.) and highest on the ranges in the east (2,500-2,600 $\mathrm{m}$ a.s.1.). The nival zone encompassed

110 the crests exceeding 2,200-2,400 m a.s.l. (Gobejishvili et al., 2011).

111 Recent studies of geomorphological processes and past climatic conditions in the southern region of the

112 Lesser Caucasus have focused on the Early to Middle Pleistocene (MP) (Joannin et al., 2010; Ollivier et 113 al., 2010) and the Holocene (Joannin et al., 2013; Leroyer et al., 2016), whereas knowledge of LP

114 Caucasus environmental conditions remains limited.

115 Both pollen and macroflora studies of the Shamb section in southern Armenia indicate that the Plio-

116 Pleistocene climate was similar to that in the Mediterranean region, and was characterized by cold and dry 117 glacial periods followed by warm, locally humid interglacials (Joannin et al., 2010). The lack of 118 periglacial features within the loess sections in northern Armenia suggests an absence of permafrost in 119 that area during the Pleistocene (Wolf et al., 2016). Fluvio-lacustrine sediments in the highlands of 120 southern Armenia indicate glacial activity during MIS 12, 6, and 4, as well as temperate and humid conditions during MIS 3 and MIS 1 (Ollivier et al., 2010). The reconstruction of the vegetation, fire and climate history in the 10,000-year record of Zarishat fen, located in the steppe grasslands of Armenia, provides snapshots of the shift from an arid and cold Early Holocene to a more humid and warmer MidLate Holocene at 8,200 cal. BP. Furthermore, fire history and sedge-based fen development recorded drier phases at approximately 6,400, 5,300-4,900, 3,000, 2,200-1,500 and 400 cal. BP (Joannin et al., 2013). The pollen-inferred climate reconstruction in Vanevan peat (south-eastern shore of the Lake Sevan, Armenia) complements the pollen study at Zarishat by documenting open-land vegetation to ca. 7,700 cal. BP, followed by a more forested landscape during the Mid Holocene (to ca. 5,700 cal. BP) compared to today and ending with open land vegetation up untill 5,100 cal. BP (Leroyer et al., 2016).

\subsection{Present regional environment}

131 The present-day climate of the southern area of the Lesser Caucasus is mild and mostly subtropical. The 
mountains. The hottest months are July and August, with mean temperatures of $22^{\circ} \mathrm{C}$ and $21^{\circ} \mathrm{C}$, 134 respectively. January and February are the coldest months with average temperatures fluctuating between $135-1^{\circ} \mathrm{C}$ and $0^{\circ} \mathrm{C}$. Mean annual precipitation varies between 480 and $840 \mathrm{~mm}$ depending on the zone: $410-480$ $136 \mathrm{~mm}$ in the lowlands, and 560-840 $\mathrm{mm}$ in the highlands (Arakelyan et al., 2011).

137 The mountainous nature of the region results in a diverse array of associated landscapes ranging from sand 138 deserts and semi-deserts situated at $400 \mathrm{~m}$ a.s.1. to alpine meadows and carpets at 3,000 $\mathrm{m}$ a.s.1, from xeric 139 mountain formations to wetland vegetation, or from mesophile forest to feather grass steppes (Fayvush 140 and Aleksanyan, 2016).

141 Karin Tak cave is located close to the boundary between a semi-arid subtropical climate characterized by 142 semi-deserts or dry steppe, and a region with a thermo-moderate humid climate that supports forests. The 143 general pattern of present vegetation is of hornbeam (Carpinus caucasica) and oak (Quercus iberica) 144 woodland regrowth around the cave-site. At lower elevations (topographically) the forest is composed of about $90 \%$ hornbeam; however, at higher elevations (towards the cave entrance), the character of the tree cover is different with ash (Fraxinus excelsior), maple (Acer campestre), hornbeam, juniper (Juniperus sp.) and plum (Prunus spp.) present. Proximal to Karin Tak cave, the forest looks to be in a stage of secondary growth after human disturbance (clearing) ca. 50 years ago.

Although the south-eastern Lesser Caucasus has not been thoroughly investigated, present ecosystems are typically associated with biodiversity richness, and the diverse herpetofauna of the region (Arakelyan et al., 2011) suggests that the diversity within other groups of animals might be equally high. Furthermore, the territory is part of the Caucasian biogeographical region, which is an important center of endemism: the World Wildlife Fund for Nature has identified it as a Global 200 Ecoregion, and Conservation International has identified it as a global "hotspot" (one of the world's 25 biologically richest and endangered regions) (Arakelyan et al., 2011). The high levels of diversity are supported by the complex 156 relief and different altitudes producing a high variety of ecosystems and microclimates and by the 
157 biogeographical position of the region at the crossroads of faunal exchange between Africa, Europe and 158 Asia. Many of the species that occur here are at the edge of their range, or are endemic populations, and 159 are therefore of major importance for modern conservation efforts (Blain, 2016).

\section{Materials and Methods}

\subsection{Excavation and sampling}

162 The first brief scientific description of the cave was completed in 2011 followed by preliminary archaeological surveys in 2014 and 2015. Large-scale excavations at the site started in 2016 and continued 164 in 2017 and 2018. The fossil material presented here was recovered from the inner chamber of Cave 1 165 during the the 2015 exploratory field season. In 2015, Pit 1 was excavated in one square meter areas (A 166 and B) to a depth of $50 \mathrm{~cm}$ below the present day cave floor (Fig. 3). The stratigraphy of the excavated pit 167 revealed visible differences in the sedimentary sequence. Currently, it is unknown whether the differences 168 are due to post-depositional mineral staining or mixing of deposits. To minimize bias in the chronology, 169 which might be caused by mixed sediments, the analised bones were sampled exclusively from the area A, 170 from which where all dated specimens were collected. This confined the number of facies to four with 171 four dated bones. 


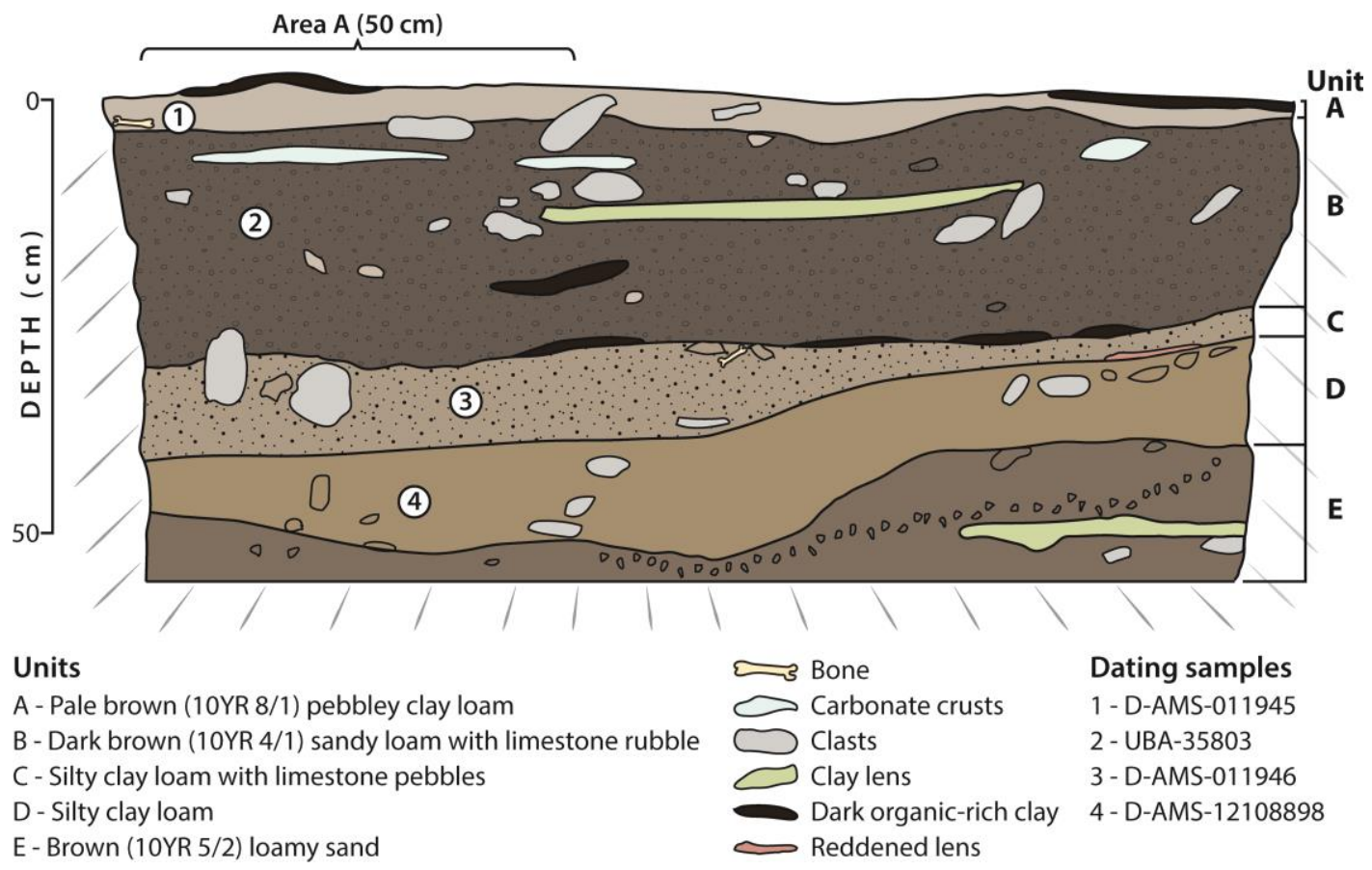

173 Fig. 3. The stratigraphy of excavated Pit 1. Studied material was recovered from the first $50 \mathrm{~cm}$ of area A.

174 The soil colors are referenced to a Munsell Color System. [1.5-column fitting image]

175 The bones acquired during the field season were excavated in situ, following standard paleontological 176 methods, which include three-dimensional recording and registration of finds (Grant et al., 2005).

177 Excavated sediment was removed (in $5 \mathrm{~cm}$ thick stratigraphic splits) for dry sieving with 2- and 0.5-mm 178 sieves to recover small specimens. All finds were brushed and dry cleaned in a field laboratory and stored 179 in airtight and opaque bags. Contamination reduction methodologies (Allentoft, 2013) were employed 180 during all phases of fieldwork, in order to minimize contamination of fossils with exogenous DNA.

$181 \quad$ 3.2. $\quad$ Studied material

182 About 500 bones were recovered during the 2015 field season. The fossils were highly fragmented and 183 morphologically indistinct, only ca. 50 bones (approximately $1 \%$ of all excavated fossils) preserved taxonomically significant morphological features. All osteological remains were well-preserved physically (with visible original organic material) and were very light to light brown with waxy to matte lusters. 
186 Permineralization and other physical diagenetic alterations were limited to $1 \mathrm{~mm}$ thick coatings of 187 pyrolusite $\left(\mathrm{MnO}_{2}\right)$ on 1-3\% of bone surfaces.

188 3.3. Sample preparation and DNA extraction

189 Five bulk bone collections (total of 250 bones) from the Karin Tak cave were analyzed at the TRACE 190 (Trace Research Advanced Clean Environment) aDNA facility at Curtin University, Western Australia.

191 For bone grinding, morphologically indistinct fossils were subsampled into pools of 50 bone fragments 192 representing different nominal units (10 $\mathrm{cm}$ each; Table 1). Each pool was ground to a fine bone powder 193 using a Retsch PM200 Planetary Ball Mill. To ensure that only bones of roughly equal size were pooled 194 together, larger bones were added to the pool by breaking off a smaller piece or by drilling the bone for 30 195 seconds using a Dremel drill and adding the resulting bone powder to the pool.

196 Table 1. Bone material from Karin Tak cave subjected to aDNA analysis.

\begin{tabular}{ccccc}
\hline Sample ID & Field Season & N of Bones & Depth (mm) & Primers \\
\hline \hline AD 2372 & 2015 & 50 & $0-100$ & 12 Sv5, Mam16S \\
AD 2373 & 2015 & 50 & $100-200$ & $12 S v 5$, Mam16S \\
AD 2374 & 2015 & 50 & $200-300$ & $12 S v 5$, Mam16S \\
AD 2375 & 2015 & 50 & $300-400$ & $12 S v 5$, Mam16S \\
AD 2376 & 2015 & 50 & $400-500$ & $12 S v 5$, Mam16S \\
\hline
\end{tabular}

197

DNA was extracted from the bulk bone pools by dissolving $100 \mathrm{mg}$ bone powder in a lysis buffer consisting of $0.49 \mathrm{M}$ EDTA, $20 \mathrm{mM}$ Tris- $\mathrm{HCl}$ (pH 8.0), $10 \mathrm{mM}$ DTT, $10 \%$ Triton X-100 and $1 \mathrm{mg} / \mathrm{mL}$ proteinase $\mathrm{K}$, followed by incubation overnight at $55^{\circ} \mathrm{C}$. Next, samples were centrifuged for 10 min at $13,000 \mathrm{rpm}$ and the supernatant concentrated to a volume of $50 \mu \mathrm{l}$ using 30,000 MWCO Vivaspin 500 centrifugal concentrators. Subsequently, concentrated DNA was purified using a MinElute polymerase chain reaction (PCR) Purification Kit (Qiagen) following the manufacturer's instructions, except for the use of a modified binding buffer optimized for ancient DNA $(0.26 \mathrm{~mL}$ of $100 \%$ isopropanol, $0.325 \mu \mathrm{L}$ of 

$\mu \mathrm{L}$ in Ultrapure water).

\subsection{Amplification and sequencing}

DNA was amplified using two sets of primers, 12Sv5 (FWD-TAGAACAGGCTCCTCTAG, RVS-

TTAGATACCCCACTATGC) and Mam16S

(FWD-CGGTTGGGGTGACCTCGGA, RVS-

GCTGTTATCCCTAGGGTAACT), targeting a short section of the mitochondrial $12 S$ and $16 S$ rRNA

gene regions, respectively, following the methods of Seersholm et al. (2018). DNA reads were sequenced on the MiSeq platform. After DNA sequencing, raw FASTQ files were filtered using Obitools (http://metabarcoding.org/obitools), discarding unique DNA reads shorter than 80 base pairs or represented by less than five copies. Reads that were likely to be a result of PCR error were filtered out using obiclean (obiclean -r $0.2-\mathrm{d} 2-\mathrm{H}$ ) and sumaclust in two steps: 'sumaclust $-\mathrm{R} 0.5$-t 0.95 ' and 'sumaclust -R 0.01 -t 0.93 '.

3.5. Faunal analysis

The DNA reads were queried against the NCBI nt database using BLAST, set to report up to 100 of the best hits to the database per read. For taxonomic assignments, BLAST files were parsed using the blast_getLCA algorithm (Seersholm et al., 2018), which assigns reads to the lowest common ancestor of the best hits to the database for each DNA read. Thereafter, raw taxonomic assignments were individually assessed by an experienced operator, correlating each assignment with data on species known to inhabit the area and data on relevant species missing from the reference database. Based on this, certain nodes were either upgraded to species level or downgraded to genus or family level. For instance, the read initially assigned to Ursus, had a $100 \%$ match with the reference sequences of Ursus maritimus and Ursus arctos. As Ursus maritimus does not inhabit the area, this assignment was upgraded to Ursus arctos. 
Anatomical identifications and morphological taxonomic affiliation of the faunal remains were carried out based on osteological catalogs (Schmid, 1972; Hillson, 2005) and comparative collections of recent specimens.

To estimate differences in the taxonomic composition of identified fauna in different time periods, correspondence analysis was conducted using SPSS ver. 19 software package (SPSS Inc.).

\subsection{Dating}

232 The chronology is based on Accelerator Mass Spectrometry (AMS) ${ }^{14} \mathrm{C}$ ages, performed in Direct AMS lab, Washington, USA, and CHRONO centre, Queens University Belfast, UK, on four bones representing different depths $(1-47 \mathrm{~cm})$ of excavated area A. The dating suggested an age from 25,683- 24,803 to 34,486 - 33,657 cal. BP for the first $40 \mathrm{~cm}$ while the age of sediments below $46 \mathrm{~cm}$ exceeded the radiocarbon dating range of 41,700 $\mathrm{BP}$ (Table 2). The dating results illustrate that some stratigraphic disturbance may have occurred in the upper layers, while the deeper strata maintain a consistent chronological succession.

Table 2. Accelerator Mass Spectrometry ${ }^{14} \mathrm{C}$ dates. Gelatin ${ }^{1}-0.45 \mu \mathrm{m}$-filtered gelatin from alkaliextracted, demineralized collagen; Gelatin ${ }^{2}>30 \mathrm{kDa}$ gelatin from demineralized collagen.

\begin{tabular}{ccccccc}
$\begin{array}{c}\text { AMS Lab } \\
\text { Number }\end{array}$ & $\begin{array}{c}\text { Sample } \\
\text { Dated }\end{array}$ & $\begin{array}{c}\text { Depth } \\
(\mathbf{m m})\end{array}$ & $\begin{array}{c}\text { Chemical } \\
\text { Fraction }\end{array}$ & $\begin{array}{c}\boldsymbol{\delta}^{\mathbf{1 3}} \mathbf{C \%} \\
(\text { VPDB })\end{array}$ & $\begin{array}{c}{ }^{\mathbf{1 4}} \text { Age } \pm \text { 1 SD } \\
\text { RC yr BP }\end{array}$ & $\begin{array}{c}\text { Cal BP Range 2 } \\
\text { SD (95.4\% C.I.) }\end{array}$ \\
\hline \hline D-AMS-011945 & Bone & 80 & Gelatin $^{1}$ & -10.2 & $24,589 \pm 149$ & $27,013-26,326$ \\
UBA-35803 & Bone & 230 & Gelatin $^{2}$ & -14.1 & $22,947 \pm 204$ & $25,683-24,803$ \\
D-AMS-011946 & Bone & 370 & Gelatin $^{1}$ & -17.1 & $32,148 \pm 185$ & $34,486-33,657$ \\
D-AMS-1210-8898 & Bone & 470 & Gelatin $^{1}$ & -17.7 & $>41,700$ & Beyond calibration \\
\hline
\end{tabular}

\section{Reconstructed faunal composition}

\subsection{Taxonomic identification}

The main feature of the Karin Tak fossil assemblage is a high rate of fragmentation. The main factors 
245 compaction, high humidity, trampling by large animals and anthropogenic modifications. From the LP 246 assemblage only ca. 50 bones bear taxonomically significant diagnostic features enabling identification.

247 The morphological taxonomic identification revealed only six taxa belonging to five mammalian families 248 (Fig. 4), representatives of which are currently inhabiting the region.

249

250

251

252

253

254

255

256

257

258

259

260

261

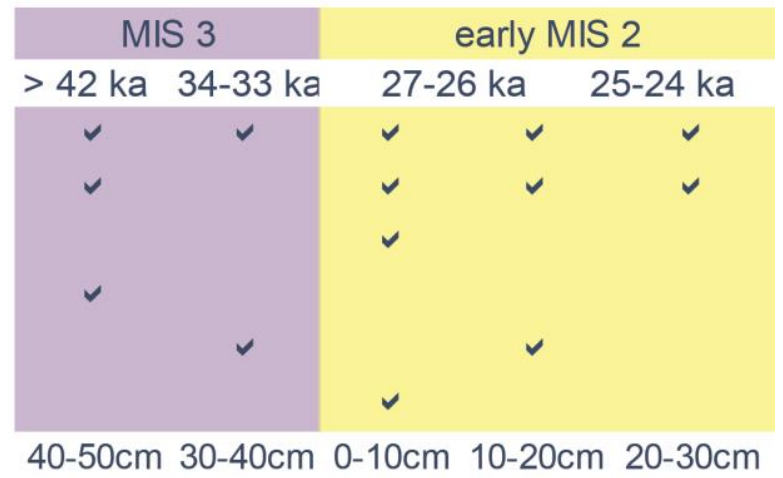

Fig. 4. Morphologically identified taxonomic composition in chronologically different frames (years cal. BP). The chronology illustrates stratigraphic disturbance in the upper layers, while the deeper strata maintain a consistent chronological succession. [1.5-column fitting image]

The morphologically reconstructed set of taxa is insufficient for comprehensive description of ancient faunal composition and dynamics. Hence, to obtain a more complete pattern of the actual ancient faunal diversity we endeavored to acquire additional information from fragmented fossils using modern molecular techniques. To complement the morphology-based data we genetically identified taxa from five bulk bone pools totaling 250 morphologically non-diagnostic bone fragments. The genetic screening of fossil bones revealed a high faunal diversity between ca. > 42 and 24 ka (Fig. 5). We identified a total of 27 different taxa, represented by 11 mammalian and three avian families. The majority of the sequences obtained were assigned to a species (13 specimens), however, in some cases, identification was restricted to a genus (nine taxa), subfamily (three taxa) or family (two taxa; Fig. 5). 


\begin{tabular}{|c|c|c|c|}
\hline Falconidae & Falconinae & Falco & \\
\hline Phasianidae & Perdicinae & Alectoris & \\
\hline \multicolumn{4}{|l|}{ Passeridae } \\
\hline \multirow{3}{*}{ Bovidae } & \multirow{2}{*}{ Caprinae } & Capra & Capra aegagrus \\
\hline & & Ovis & \\
\hline & Antilopinae & Gazella & Gazella subgutturosa* \\
\hline \multirow{2}{*}{ Cervidae } & Cervinae & Cervus & Cervus elaphus \\
\hline & Capreolinae & Capreolus & Capreolus capreolus \\
\hline Equidae & Equinae & Equus & \\
\hline Canidae & Caninae & Canis & Canis lupus \\
\hline \multirow{2}{*}{ Ursidae } & Ursinae & Ursus & Ursus arctos \\
\hline & Ursinae & Ursus & Ursus thibetanus* \\
\hline Felidae & Pantherinae & Panthera & \\
\hline \multirow[b]{2}{*}{ Hyaenidae } & \multirow{2}{*}{ Hyaeninae } & Crocuta & Crocuta crocuta* \\
\hline & & Hyaena & Hyaena hyaena \\
\hline Mustelidae & Mustelinae & Martes & Martes martes \\
\hline \multirow{2}{*}{ Cricetidae } & Arvicolinae & Arvicola & Arvicola amphibius \\
\hline & Cricetinae & Mesocricetus & Mesocricetus radde $i^{*}$ \\
\hline Rhinolophidae & Rhinolophinae & Rhinolophus & \\
\hline \multirow{2}{*}{ Vespertilionidae } & Myotinae & Myotis & \\
\hline & Vespertilioninae & Plecotus & Plecotus macrobullaris \\
\hline
\end{tabular}

262

263 Fig. 5. Taxa identified via the bulk bone method in different temporal intervals (years cal. BP).

264

265

266

267

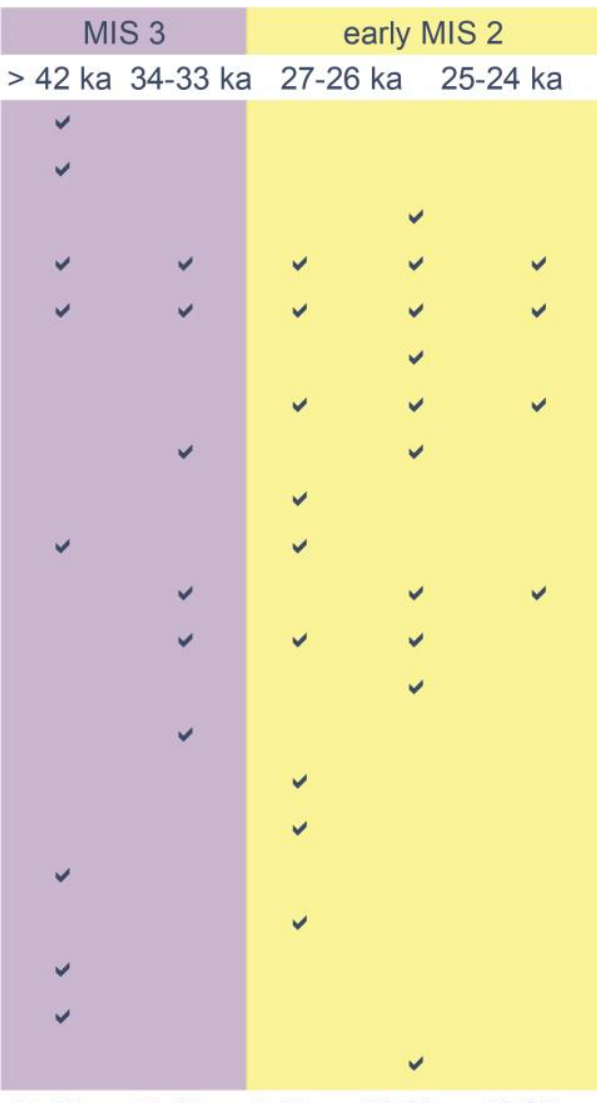

$40-50 \mathrm{~cm} \quad 30-40 \mathrm{~cm} \quad 0-10 \mathrm{~cm} \quad 10-20 \mathrm{~cm} \quad 20-30 \mathrm{~cm}$ *regionally extinct species. [1.5-column fitting image]

The genetically recovered mammalian taxonomic composition is rich and diverse, and predominantly consists of extant wild species together with regionally extinct ones. Large mammals dominate the record, with eight families representing 18 taxa $(\sim 66 \%)$. Small mammals are considerably less common in our dataset represented by six taxa $(\sim 22 \%)$. The identified avian fauna comprises three extant taxa representing, in aggregate, $\sim 11 \%$ of the identified assemblage.

Overall, the genetically identified assemblage agrees with the morphologically-based reconstruction, with the exception of Bos and Meles, which appear to be absent in the collection screened by the bulk bone method.

4.2. MIS 3 faunal diversity (> 42-33 ka) 
274 Samples dated to ca. > 42,000 and 34,486-33,657 cal. BP are associated with the last phase of interstadial 275 MIS 3 (57-29,000 BP) characterized by a relatively warm and humid climate (Ollivier et al., 2010). The morphological and genetic identification of MIS 3 Karin Tak sub-samples revealed 14 extant and extinct 277 mammalian and avian taxa (Fig 6, A).

278 The large mammals are represented by ungulate and carnivore species. Capra aegagrus (bezoar goat) and Ovis sp. (sheep) constitute the two dominant groups throughout the assemblage and are distinctive of dry open environments. The other ungulate taxa identified are: Capreolus capreolus (roe deer), typical for forested zones and shrublands; Equus sp. and Bos sp. associated with dry open environments. The carnivore assemblage is represented by Canis lupus (grey wolf) and Ursus arctos (brown bear), both inhabiting a great variety of habitats (dry Asian steppes, Arctic shrublands and temperate forests), as well as Ursus tibethanus (Asiatic black bear) and Crocuta crocuta (spotted hyena), both of which are currently absent in the region (Dal', 1954; Hayrapetyan et al., 2017). Spotted hyenas, typical of dry open habitats, are known to have become extinct from northern Eurasia about $40 \mathrm{ka}$, but persisted until ca. $31 \mathrm{ka}$ in the south and west of Europe (Stuart and Lister, 2013) and appear to have survived in the South Caucasus region (Karin Tak cave) until at least ca. 34-33 ka. Similarly, following the last interglacial, the range of the Asiatic black bear, associated with forested habitats, was significantly reduced and it disappeared from Europe, the Caucasus and northern Asia (Kosintsev et al., 2016), but is shown to survive in the Karin Tak region until ca.34-33 ka. Additionally, these two species (C. crocuta, U. tibethanus) have been identified in the neighboring Azokh cave, indicating their presence in the Lesser Caucasus region at least since the MP (Van der Made et al., 2016).

The existence of wetland in the vicinity of the site is proved by the presence of the only representative of 295 rodents in this assemblage: Arvicola amphibius (water vole) commonly inhabiting territories around rivers and streams. The small mammals are generally very scarce in these layers and include extant horseshoe bat (Rhinolophus sp.) and mouse-eared bat (Myotis sp.). 
298 The identified bird assemblage consists of only two contemporary representatives (Dal', 1954; Klem, 299 1997): Falco, a diverse genus comprising birds of prey inhabiting a variety of habitats, and Alectoris, a 300 genus of partridges, mainly associated with dry, open and mountainous environments.

\section{$301 \quad$ 4.3. Early MIS 2 faunal diversity (27-24 ka)}

MIS 2 (29,000-14,000 BP) coincides with the beginning of the last glacial cycle and marks the onset of the LGM (Clark et al., 2009). The taxonomic composition of layers dated between 27,013-26,326 and 25,683-24,803 cal. BP is richer (in comparison to MIS 3 ones), including 22 taxa of extant and extinct mammals and birds identified (Fig. 6, A). Here, large mammals are most commonly encountered in the record and dominated by ungulates such as Caprinae (Ovis sp., Capra sp., and C. aegagrus), Bovinae (Bos sp.), Cervinae (Cervus elaphus), Capreolinae (C. capreolus), Equinae (Equus sp.) and Antilopinae (Gazella subgutturosa) subfamilies. G. subgutturosa (goitered gazelle) is associated with a semi-arid steppe environment and mostly occurs in foothills and mountain valleys. It is currently extirpated from the south-eastern Lesser Caucasus and appears only through Oman, across the Arabian Peninsula to southern Turkey, following the steppes of Central Asia into central Mongolia (Wacher et al., 2011). Although presumably hunted to extinction in the Near East by Neolithic hunter-gatherers (Legge and RowleyConwy, 1987), the goitered gazelle appears to have survived in Armenia until the Early Iron Age (Mirzoyan and Manaseryan, 2016). Carnivores are also frequently registered, with the genera Ursus (U. arctos and U. tibetanus), Canis (C. lupus), Hyaena (H. hyaena), Panthera sp., and small carnivores Martes martes (pine marten) and Meles meles (Eurasian badger). The striped hyena (H. hyaena) occurs in open habitat or in arid to semi-arid environments, whereas red deer, pine marten and Eurasian badger inhabit deciduous, mixed and coniferous woodlands. 
A

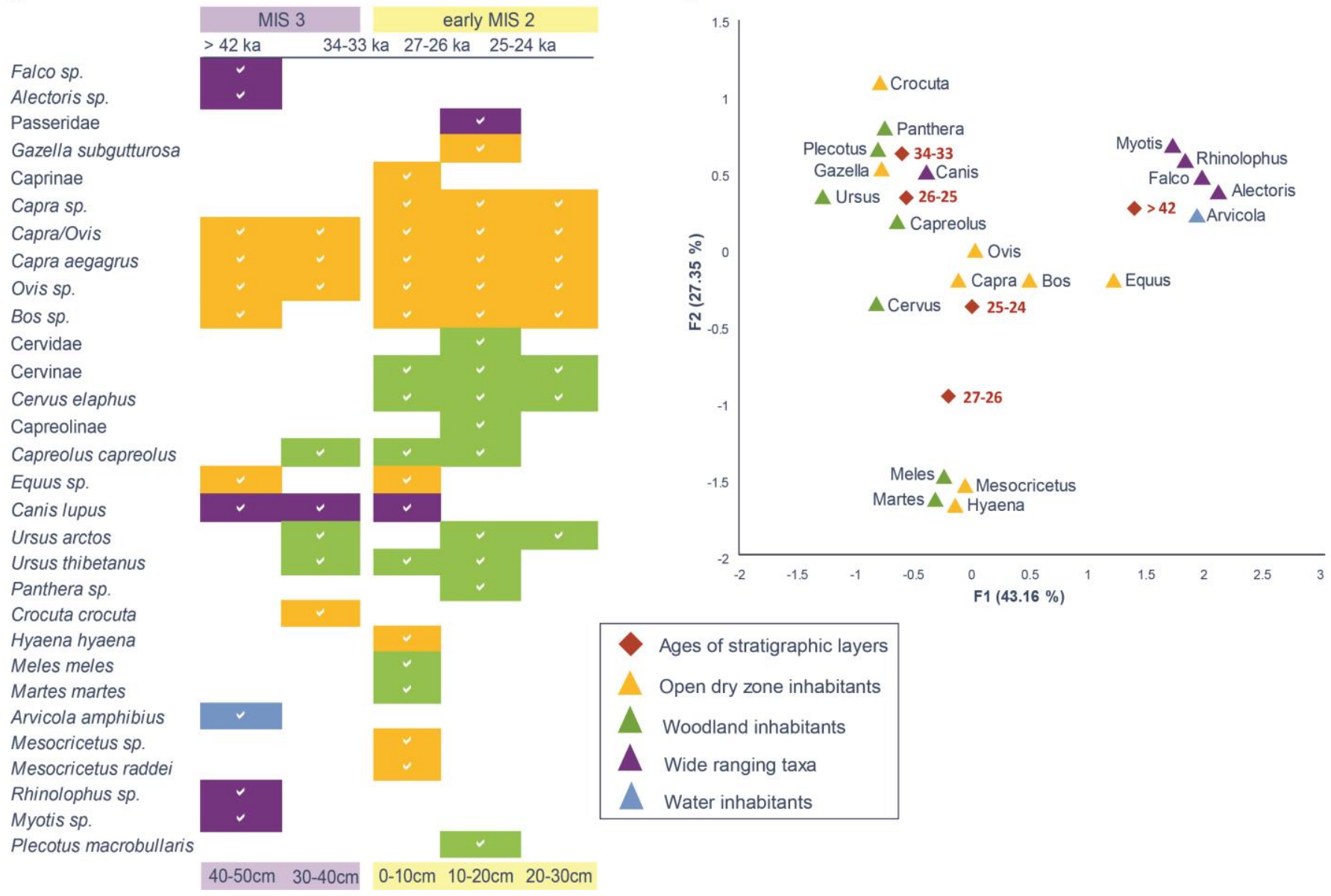

320 Fig. 6. (A) Taxonomic composition of samples identified by morphological and bulk bone methods in

321 different time frames. (B) Visualization of the results of correspondence analysis based on the abundance

322 variation of taxa trough time. [2-column fitting image]

323 The reconstructed small mammals assemblage includes Mesocricetus raddei (Ciscaucasian hamster), 324 associated with shrublands and open grassland, Plecotus macrobullaris (mountain long-eared bat) typical 325 to oak shrub, as well as beech and pine forests and shrublands. It is noteworthy that the Ciscaucasian 326 hamster, extending in lowlands of the North Caucasus (Gromov and Ebraeva, 1995) and only bordering 327 Georgia in the northeast, has not been previously described from the south-eastern Lesser Caucasus, and 328 therefore this species might be considered a locally extinct taxon. 
The MIS 2 assemblage revealed only one family of birds: Passeridae (old world sparrows), whose representatives are widely distributed through the region and mostly associated with dry environments (Dal', 1954; Klem, 1997).

To visualize genetic and morphological variation in the abundance of identified taxa across different time periods, correspondence analysis was applied (Fig. 6, B). The results revealed four clusters of taxa associated with different time periods; in all clusters the proportions of forest adapted and arid associated taxa are roughly equal. The only exception is the $>42 \mathrm{ka}$ cluster, where taxa are associated with a wide range of environments together with a single species (Arvicola amphibious) indicating a humid climate.

\section{Regional comparison}

The faunal record from Karin Tak is represented by a diverse set of taxa: some that are still common and widespread, others that are rare today and have highly restricted distributions, and some that are regionally extinct. The identified faunal assemblage offers unique insights into the MIS 3-early MIS 2 transition and onset of LGM in the Lesser Caucasus. The reconstructed MIS 3 assemblage is rich with arid-adapted ungulates (Bos sp., Capra sp., Ovis sp. and Equus sp.) and their predators-wolves (C. lupus), hyenas (C. crocuta) and forest inhabitants such as deer (C. elaphus, C. capreolus) and bears (U. arctos, $U$. tibethanus). The early MIS 2 collection comprises a similar set of both arid and humid environment occupants. The MIS 2 assemblage also includes species typical for forested zones (pine marten $(M$. martes), Eurasian badger (M. meles), Panthera sp.) and open dry landscapes (gazelle (G. subgutturosa), hyena (H. hyaena), hamster $(M$. raddei $))$. The correspondence analysis based on the abundance variation of taxa trough time did not reveal a clear clustering of forest and arid environment associated taxa in the examined time period. Although large mammals are rather imprecise indicators of climatic conditions, the data support continuity of the same biota from MIS 3 to early MIS 2, with species distinctive of 
with the cave currently surrounded by a thick forest on the mountain slopes and a steppe located in the 353 low land.

354 The assemblage of Karin Tak is supplemented by the neighboring LP sites of Ortvale Klde (Bar-Oz and 355 Adler, 2005), Satsurblia (Pinhasi et al., 2014) and Dzudzuana (Bar-Yosef et al., 2011) in Georgia; Hovk-1 356 (Pinhasi et al., 2011), Kalavan-2 (Ghukasyan et al., 2011) and Aghitu-3 (Kandel et al., 2017) in Armenia, where bone and lithic-rich collections indicate that hominins and fauna prospered throughout much of the region during the LP. Comparison with the faunal assemblages of regional LP sites revealed many 359 mammalian species similar to the ones from Karin Tak (Supplementary information, Table A1). The cave deposits at Aghitu-3 have yielded both arid zone (Ovis, Capra, Equus, Bos/Bison) and forest (C. elaphus, 361 Vulpes vulpes, Sus scrofa) associated mammals from the 39,000-24,000 cal. BP horizons. Similarly, Hovk-1 Unit 4 (35,000 cal. BP) assemblage is dominated by forest taxa (V. vulpes, C. elaphus, C. capreolus, M. meles and Martes foina) with few arid area representatives (C. aegagrus and Lepus europaeus). Likewise, the LP faunal assemblages of Georgian sites Dzadzuana (Unit D at 35-32,000 cal. BP and Unit C at 27-24,000 cal. BP), Satsurbia (Layers B/III and B/II at 26-24,000 cal. BP) and Ortvale Klde (Layers 4 at 40-26,000 cal. BP and 3 at 26-22,000 cal. BP) are often dominated by open-landscape taxa (Capra, Ovis, Equus, and Bos/Bison) together with forest associated ones such as U. arctos, V. 368 vulpes, C.elaphus and C. Capreolus. These results demonstrate that Upper Palaeolithic hunters targeted both forest-dwelling and open landscape ungulates.

370 The overall composition of the micro mammalian species in the LP sites shows a strong biogeographic 371 affiliation with those of the Eastern Mediterranean area and Asia Minor. In both MIS 3 and MIS 2 372 collections, the proportion of small mammals associated with open grassland is markedly higher; those 373 being most probably captured in open grasslands by predators in a setting where forests are located in the 374 vicinity of steppes. 
375 The recovered animal diversity indicates general continuity in the composition of fauna in this region 376 since the LP with only a few extinct taxa. This result, along with the finding of late-surviving taxa, 377 demonstrates that during the MIS 3-MIS 2 transition, the region sheltered a wide range of animals of the 378 temperate biota and could be considered a refugia for several animal species.

379 The pockets of relatively stable warm climate are also distinguished by the presence of Colchic and Hyrcanian forests, which represent refugia for the Tertiary relict plants and animals (Browicz, 1989; Denk et al., 2001; Ramezani et al., 2008; Tarkhnishvili et al., 2012; Fig. 1). Additionally, patches of mesophilic Tertiary plants are currently sporadically dispersed between the Black and Caspian seas (Mulkidjanyan, 1967), indicating the presence of multiple spatially confined refugia, where species survived the cold and aridity of the glacial period. Furthermore, the faunal and floral elements of Azokh cave (ca. 36,000 m distance from the Karin Tak) provide detailed information on the MP environment. The large mammals (Van der Made et al., 2016) and charcoal (Allué, 2016) indicate deciduous woodland conditions, while small mammals (Parfitt, 2016), amphibians and reptiles (Blain, 2016) point to an open steppe environment for the region, thus demonstrating woodland in the vicinity of the cave, and open steppe areas not far away. In whole, the results of excavations at both Azokh cave and Karin Tak cave provide strong evidence that the south-eastern Lesser Caucasus served as a refugium during the MP and early LP when the region was surrounded by arid, hyper-arid and periglacial landscapes, with extensive alpine glaciation in surrounding mountains (Fernandez-Jalvo, 2016). These pieces of evidence provide solid support for the increasing recognition of the south-eastern Lesser Caucasus as a climatically and ecologically stable region at least since the MP despite significant global climatic changes.

\section{Conclusion}

The fossil fauna of Karin Tak cave was explored to improve the reconstruction of environmental conditions in the south-eastern Lesser Caucasus during the LP. The present study contributes to our 
region based on morphological and genetic identification of fossil bones. The taxonomic assemblage 400 indicates general continuity in faunal composition in this region during LP, with only a few extinct taxa. 401 This allows us to suggest that cold and arid MIS 2 did not cause a dramatic change in faunal makeup, and 402 between ca. 42 and 24 ka the cave was close to the boundary between arid subtropical and humid climate 403 regions (with the latter supporting forests), a pattern similar to the present environment of the site.

Based on these results we consider Karin Tak cave to be a paleontological site of great regional 405 importance, where the remarkable preservation conditions allow for molecular reconstruction of the 406 prehistoric ecosystem. The outcomes highlight the potential of ongoing excavations that will delve deeper into the past to make a significant contribution to our understanding of paleoenvironment of the Lesser Caucasus during the Pleistocene and Holocene.

\section{Acknowledgments}

We thank the National Academy of Sciences, Science Committee of the Ministry of Education and Science of Armenia and Forrest Research Foundation (to F.V.S.) for financial support. We are grateful to Mr. Eddie Torossian for providing tools and equipment for the excavations and his active participation in the excavations. We are hugely indebted to anonymous donors who have provided financial assistance to the project enabling us to carry out fieldwork. We also thank Polish and Armenian student volunteers for their assistance in the field excavations, and James Taylor (Curtin University) for technical assistance with molecular work.

\section{Appendix A. Supplementary data}

418 The following is the Supplementary data to this article:

419 Table A1: Faunal composition of regional Late Pleistocene sites.

\section{REFERENCES}

Adler, D.S., Bar-Yosef, O., Belfer-Cohen, A., Tushabramishvili, N., Boaretto, E., Mercier, N., Valladas, 
humans in the southern Caucasus. Journal of Human Evolution. 55, 817-833. https://doi.org/10.1016/j.jhevol.2008.08.010

Adler, D.S., Tushabramishvili, N., 2004. Middle Palaeolithic patterns of settlement and subsistence in the southern Caucasus. In: Conard, N.J. (ed.). Settlement Dynamics of the Middle Paleolithic and Middle Stone Age. 2, 91-132.

Adler, D.S., Wilkinson, K.N., Blockley, S., Mark, D.F., Pinhasi, R., Schmidt-Magee, B., Nahapetyan, S., Mallol, C., Berna, F., Glauberman, P.J., Raczynski-Henk, Y., Wales, N., Frahm, E., Jöris, O., MacLeod, A., Smith, V.C., Cullen, V.L., Gasparian, B., 2014. Early Levallois technology and the Lower to Middle Paleolithic transition in the Southern Caucasus. Science. 345, 1609-13. https://doi.org/10.1126/science.1256484

Arakelyan, M.S., Danielyan, F.D., Corti, C., Sindaco, R., Leviton, A.E., 2012. Herpetofauna of Armenia and Nagorno-Karabakh. Society for the Study of Amphibians and Reptiles. Acta Herpetologica.

Allentoft, M.E., 2013. Recovering samples for ancient DNA research-guidelines for the field archaeologist. Antiquity. 87, 338.

Allué, E., 2016. Charcoal Remains from Azokh 1 Cave: Preliminary Results. In: Fernández-Jalvo Y., King T., Yepiskoposyan L., Andrews P. (eds) Azokh Cave and the Transcaucasian Corridor. Vertebrate Paleobiology and Paleoanthropology. Springer. Cham, 297-304. https://doi.org/10.1007/978-3-319-24924-7_14

Avagyan, A., Sahakan, L., Aspaturyan, N., Antonosyan, M., Yepiskoposyan L., 2018. Preliminary Overview on Geology and Paleoseismology of Karin Tak Cave (Republic of Artsakh). Proceedings of the NAS RA: Earth Sciences. 71.

Barnosky, A. D., Koch, P. L., Feranec, R. S., Wing, S. L., \& Shabel, A. B., 2004. Assessing the causes of late Pleistocene extinctions on the continents, Science. 306(5693), 70-75. $\underline{\text { http://doi.org/10.1126/science.1101476 }}$ 
447 Bar-Oz, G., Adler, D.S., 2005. Taphonomic History of the Middle and Upper Palaeolithic Faunal 448 Assemblage from Ortvale Klde, Georgian Republic. Journal of Taphonomy. 3, 185-211.

449

450

451

452

453

454

455

456

457

458

459

460

461

462

463

464

465

466

467

468

469

Bar-Yosef, O., Belfer-cohen, A., Adler, D.S., 2006. The Implications of the Middle-Upper Paleolithic Chronological Boundary in the Caucasus to Eurasian Prehistory. Anthropologie. 44, 49-60.

Bar-Yosef, O., Belfer-Cohen, A., Mesheviliani, T., Jakeli, N., Bar-Oz, G., Boaretto, E., Goldberg, P., Kvavadze, E., Matskevich, Z., 2011. Dzudzuana: an Upper Palaeolithic cave site in the Caucasus foothills (Georgia).

Antiquity.

85 , 331-349. https://doi.org/http://antiquity.ac.uk/ant/085/ant0850331.htm

Blain, H.A., 2016. Amphibians and Squamate reptiles from Azokh 1. In: Fernández-Jalvo Y., King T., Yepiskoposyan L., Andrews P. (eds) Azokh Cave and the Transcaucasian Corridor. Vertebrate Paleobiology and Paleoanthropology. Springer. Cham, 191-210. https://doi.org/10.1007/978-3-319$\underline{24924-7 \quad 9}$

Browicz, K., 1989. Systematics and Evolution Chorology of the Euxinian and Hyrcanian element in the woody flora of Asia. Plant Systematics and Evolution. 162, 305-314.

Clark, P.U., Dyke, A.S., Shakun, J.D., Carlson, A.E., Clark, J., Wohlfarth, B., Mitrovica, J.X., Hostetler, S.W., McCabe, A.M., 2009. The Last Glacial Maximum. Science. 325, 710-714. https://doi.org/10.1126/science. 1172873

Dal', S.K., 1954. Fauna of the Armenian SSR. Vol. 1. Publishing House of the Academy of Sciences of the Armenian SSR. (in Russian)

Denk, T., Frotzler, N., Davitashvil, N., 2001. Vegetational patterns and distribution of relict taxa in humid temperate forests and wetlands of Georgia (Transcaucasia). Biological Journal of the Linnean Society. 72, 287-332.

Fayvush, G.M., Aleksanyan, A.S., 2016. Habitats of Armenia. Yerevan. Institute of Botany NAS RA. 
Fernández-Jalvo, Y., King, T., Yepiskoposyan, L., Andrews, P., 2016. Introduction: Azokh Cave and the Transcaucasian Corridor. In: Fernández-Jalvo Y., King T., Yepiskoposyan L., Andrews P. (eds) Azokh Cave and the Transcaucasian Corridor. Vertebrate Paleobiology and Paleoanthropology. Springer. Cham, 1-26. https://doi.org/10.1007/978-3-319-24924-7__1

Gabunia, L., Vekua, A, Lordkipanidze, D., 2000. The environmental contexts of early human occupation of Georgia (Transcaucasia). Journal of Human Evolution. 38, 785-802. https://doi.org/10.1006/jhev.1999.0383

Gasparyan, B., Kandel, A. W., Montoya, C., 2014. Living the high life: The Upper Paleolithic settlement of the Armenian Highlands. In: Gasparyan, B., Arimura, M. (eds.). Stone Age of Armenia. A guidebook to the Stone Age archaeology in the Republic of Armenia. Center for Cultural Resource Studies, Kanazawa University, 107-131.

Ghukasyan, R., Colonge, D., Nahapetyan, S., Ollivier, V., Gasparyan, B., Monchot, H., Chataigner, C. 2010. Kalavan-2 (north of lake Sevan, Armenia): a new late Middle Paleolithic site in the Lesser Caucasus. Archaeology. Ethnology and Anthropology of Eurasia, 38, 39-51. https://doi.org/10.1016/j.aeae.2011.02.003

Gobejishvili, R., Lomidze, N., Tielidze, L., 2011. Late Pleistocene (Wurmian) Glaciations of the Caucasus 15. In: Ehlers, J., Gibbard, P.L., Hughes, P.D. (eds.). Quaternary glaciations-extent and chronology: a closer look. Elsevier, 141-147. https://doi.org/10.1016/B978-0-444-53447-7.00012-X

Grant, J., Gorin, S., Fleming, N., 2005. The archaeology Coursebook: An introduction to study skills, topics and methods. Taylor and Francis.

Grealy, A.C., Mcdowell, M.C., Sco, P., Fusco, D.A., Haile, J., Prideaux, G.J., Bunce, M., 2015. A critical evaluation of how ancient DNA bulk bone metabarcoding complements traditional morphological analysis of fossil assemblages. Quaternary Science Reviews. 128, 37-47. https://doi.org/10.1016/j.quascirev.2015.09.014 
494 Gromov, I.M., Ebraeva, M.A., 1995, Mammals of the fauna of Russia and adjacent territories. 495 Lagomorphs and rodents. St. Petersburg. (in Russian)

496 Joannin, B., Ali, A.A., Ollivier, V., Roiron, P., Peyron, O., Chevaux, S., Umr, C., Chataigner, C., 2013.

497 Vegetation, fire and climate history of the Lesser Caucasus: a new Holocene record from Zarishat 498 fen (Armenia). Journal of Quaternary Science. 29, 70-82 https://doi.org/10.1002/jqs.2679

499 Joannin, S., Cornée, J.J., Münch, P., Fornari, M., Vasiliev, I., Krijgsman, W., Nahapetyan, S., Gabrielyan, 500 I., Ollivier, V., Roiron, P., Chataigner, C., 2010. Early Pleistocene climate cycles in continental 501 deposits of the Lesser Caucasus of Armenia inferred from palynology, magnetostratigraphy, and 502 40Ar/39Ar dating. Earth and Planetary Science Letters. 291, 149-158. $503 \quad$ https://doi.org/10.1016/j.eps1.2010.01.007

504 Hillson, S., 2005. Teeth. Cambridge university press.

505 Kandel, A.W., Gasparyan, B., Allu, E., Bruch, A.A., Cullen, V.L., Frahm, E., Ghukasyan, R., Gruwier, B., 506 Jabbour, F., Miller, C.E., Taller, A., 2017. The earliest evidence for Upper Paleolithic occupation in 507 the Armenian Highlands at Aghitu-3 Cave. Journal of human evolution. 110, 37-68. $508 \quad$ https://doi.org/10.1016/j.jhevol.2017.05.010

509 Klem, D., 1997. A field guide to birds of Armenia. American University of Armenia.

510 Kosintsev, P.A., Tiunov, M.P., Gimranov, D.O., Panov, V.S., 2016. The First Finding of Asian Black 511 Bear (Carnivora, Ursidae, Ursus (Euarctos) thibetanus G. Cuvier, 1823) in the Late Pleistocene of 512 Northern Eurasia. Doklady Biological Sciences. $471, \quad 368-370$. $513 \quad$ https://doi.org/10.1134/S0012496616060041

514 Legge, A.J., Rowley-Conwy, P.A., 1987. Gazelle Killing in Stone Age Syria. Scientific American. 257, $515 \quad 88-95$ 
516 Leroyer, C., Joannin, S., Aoustin, D., Ali, A.A., Ollivier, V., Tozalakyan, P., Karakhanyan, A., Jude, F., 517 2016. Mid Holocene vegetation reconstruction from Vanevan peat (south-eastern shore of Lake 518 Sevan, Armenia). Quaternary International. 395, 5-18. https://doi.org/10.1016/j.quaint.2015.06.008

519 Lordkipanidze, D., León, M.S.P. De, Margvelashvili, A., Rak, Y., Philip, G., 2013. A Complete Skull 520 from Dmanisi, Georgia, and the Evolutionary Biology of Early Homo. Science. 342, $326-331$. $521 \quad$ https://doi.org/10.1126/science.1238484

522 Margaryan, A., Derenko, M., Hovhannisyan, H., Malyarchuk, B., Heller, R., Yepiskoposyan, L., 523 Willerslev, E., Allentoft, M.E., 2017. Eight millennia of matrilineal genetic continuity in the south 524 Caucasus. Current Biology. 27, 2023-2028.https://doi.org/10.1016/j.cub.2017.05.087

525

Mirzoyan, L., Manaseryan, N., 2016. Archaeozoological investigation of the site of Shirakavan, 3rd-1st millennia BC, Armenia. Publications de la Maison de l'Orient et de la Méditerranée, 49, 521-531.

Montoya, C., Balasescu, A., Joannin, S., Ollivier, V., Liagre, J., Nahapetyan, S., Ghukasyan, R., Colonge, D., Gasparyan, B., Chataigner, C., 2013. The Upper Palaeolithic site of Kalavan 1 (Armenia): An Epigravettian settlement in the Lesser Caucasus. Journal of Human Evolution. 65, 621-640. https://doi.org/10.1016/j.jhevol.2013.07.011

Mulkidjanyan, Y.I., 1967. Relic islands of the mesothermophilic flora of the Caucasus between Colchis and Hyrkanika. Flora and vegetation of the Armenian flora. Proceedings of the Botanical Institute of Armenia. 63, 16-18. (in Russian)

Murray, D.C., Haile, J., Dortch, J., White, N.E., Haouchar, D., Bellgard, M.I., Allcock, R.J., Prideaux, G.J., Bunce, M., 2013. Scrapheap challenge: a novel bulk-bone metabarcoding method to investigate ancient DNA in faunal assemblages. Scientific reports. 3, 3371. https://doi.org/10.1038/srep03371

Ollivier, V., Nahapetyan, S., Roiron, P., Gabrielyan, I., Gasparyan, B., Chataigner, C., Joannin, S., Cornée, J.J., Guillou, H., Scaillet, S., Munch, P., Krijgsman, W., 2010. Quaternary volcano- 
lacustrine patterns and palaeobotanical data in southern Armenia. Quaternary International. 223, 312-326. https://doi.org/10.1016/j.quaint.2010.02.008

541 Orth, A., Auffray, J. C., Bonhomme, F., 2002. Two deeply divergent mitochondrial clades in the wild 542 mouse Mus macedonicus reveal multiple glacial refuges south of Caucasus. Heredity. 89, 353-357 http://doi.org/10.1038/sj.hdy.6800147

544 Parfitt, S.A., 2016. Rodents, lagomorphs and insectivores from Azokh Cave. In: Fernández-Jalvo Y., King

545 T., Yepiskoposyan L., Andrews P. (eds) Azokh Cave and the Transcaucasian Corridor. Vertebrate 546 Paleobiology and Paleoanthropology. Springer. Cham,163-176. https://doi.org/10.1007/978-3-319$547 \underline{24924-7 \quad 7}$

548 Pinhasi, R., Gasparian, B., Nahapetyan, S., Bar-Oz, G., Weissbrod, L., Bruch, A.A., Hovsepyan, R., 549 Wilkinson, K., 2011. Middle Palaeolithic human occupation of the high altitude region of Hovk-1, $550 \quad$ Armenia. $\quad$ Quaternary $\quad$ Science $\quad$ Reviews. 3846-3857. $551 \quad$ https://doi.org/10.1016/j.quascirev.2011.09.020

552 Pinhasi, R., Meshveliani, T., Matskevich, Z., Bar-Oz, G., Weissbrod, L., Miller, C.E., Wilkinson, K., 553 Lordkipanidze, D., Jakeli, N., Kvavadze, E., Higham, T.F.G., Belfer-cohen, A., 2014. Satsurblia: 554 New Insights of Human Response and Survival across the Last Glacial Maximum in the Southern 555 Caucasus PloS one. 9, e111271. https://doi.org/10.1371/journal.pone.0111271

556 Provan, J., Bennett, K.D., 2008. Phylogeographic insights into cryptic glacial refugia. Trends in ecology 557 and evolution. 23, 564-571. https://doi.org/10.1016/j.tree.2008.06.010

558 Ramezani, E., Mohadjer, M.R.M., Ahmadi, H., Joosten, H., 2008. The Late-Holocene vegetation history 559 of the Central Caspian (Hyrcanian) forests of northern Iran. The Holocene. 18, $307-321$. $560 \quad$ https://doi.org/10.1177/0959683607086768

561 Seersholm, F. V, Cole, T.L., Grealy, A., Rawlence, N.J., Greig, K., Knapp, M., Stat, M., Hansen, A.J., 562 Easton, L.J., Shepherd, L., Tennyson, A.J.D., Scofield, R.P., Walter, R., Bunce, M., 2018. 
anthropogenic impacts revealed by New Zealand-wide ancient DNA survey. Proceedings of the National Academy of Sciences. 115, 7771-7776. https://doi.org/10.1073/pnas.1803573115

565

Schmid, E., 1972. Atlas of animal bones for prehistorians. Archaeologists and Quaternary Geologists: Elsevier Publishing Company.

Stone, A.C., 2000. Ancient DNA from skeletal remains. Biological Anthropology of the Human Skeleton Wiley. New York, 351-372.

Stuart, A.J., Lister, A.M., 2013. New radiocarbon evidence on the extirpation of the spotted hyaena (Crocuta crocuta (Erxl.) in northern Eurasia. Quaternary Science Reviews. 96, 108-116. https://doi.org/10.1016/j.quascirev.2013.10.010

Tarasov, P.E., Volkova, V.S., Iii, T.W., Guiot, J., Andreev, A.A., Bezusko, L.G., 1846. Last glacial maximum biomes reconstructed from pollen and plant macrofossil data from northern Eurasia. Journal of Biogeography. 27, 609-620.

Tarkhnishvili, D., Gavashelishvili, A., Mumladze, L., 2012. Palaeoclimatic models help to understand current distribution of Caucasian forest species. Biological Journal of the Linnean Society. 105, 231-248. https://doi.org/10.1111/j.1095-8312.2011.01788.x

Van der Made, J., Torres, T., Ortiz, J. E., Moreno-Pérez, L., Fernández-Jalvo, Y., 2016. The new material of large mammals from Azokh and comments on the older collections. In: Fernández-Jalvo Y., King T., Yepiskoposyan L., Andrews P. (eds) Azokh Cave and the Transcaucasian Corridor. Vertebrate Paleobiology and Paleoanthropology. Springer. Cham, 117-162. https://doi.org/10.1007/978-3-319$\underline{24924-7 \quad 6}$

Wacher, T., Wronski, T., Hammond, R.L., Winney, B., Blacket, M.J., Hundertmark, K.J., Mohammed, O.B., Bleidorn, C., 2011. Phylogenetic analysis of mitochondrial DNA sequences reveals polyphyly in the goitred gazelle (Gazella subgutturosa). Conservation Genetics. 12, 827-831. https://doi.org/10.1007/s10592-010-0169-6 
587 Wolf, D., Baumgart, P., Meszner, S., Fülling, A., Haubold, F., Sahakyan, L., Faust, D., 2016. Loess in 588 Armenia - stratigraphic findings and palaeoenvironmental indications. Proceedings of the 589 Geologists' Association. 127, 29-39. https://doi.org/10.1016/j.pgeola.2016.02.002 